\title{
KINERJA DAN PERBANYAKAN PARASITOID Tetrastichus brontispae PADA HAMA DAUN KELAPA : Brontispa longissima GESTRO (COLEOPTERA : CHRYSOMELIDAE) DI KABUPATEN ENDE - FLORES
}

\author{
Sri Wahyuni \\ Program Studi Agroteknologi, Fakultas Pertanian Universitas Flores \\ sriwahyuni_uniflor@yahoo.co.id
}

\begin{abstract}
The multiplication and performance of Tetrastichus brontispae parasite on Brontispa longissima coconut leaves disease in Kabupaten Ende Flores

Brontispa longissima Gestro (Coleoptera: Chrysomelidae) is one of the important pests that attack the palm plants in Southeast Asia. There is a reported decline in the productivity of palm plants when the pest attack reaches $30-40 \%$ with $5 \%$ of the plants attacked dying. B. Longissima pest attacks plants at all stages of life, but its attack is most prevalent when plants reach the age of 4-5 years. The spread of pests $B$. Longissima has been reported in the district of Ende, Nangakeo and Ndona in 13 villages with a total area of 150 ha plantation consisting of 15,000 coconut trees included in the category of severe intensity of attacks. There have been attempted control measures with the release of natural enemies Tetratichus brontispae but not much success has been seen .

This study aimed to find out: The dominant type of the parasite in the district of Ende. T. Brontispae were propagated and maintained in the laboratory using, augmentation techniques, conservation or disposal was to be done. Colonies of the propagated parasite $T$. brontispae were then released in the field. The factors causing $T$. Brontispae control failure, the population of B. longissima in the field, possibly the need for augmentation or conservation of $T$. brontispae and the right time to make the release of parasite in the field was important. This research is expected to be useful as a basis in formulating an appropriate control program, in order to control the pest $B$. longissima in the field. The experiment was conducted from January to June 2010 at Nangakeo, Ndona and Ende districts.

Implementation of the research was divided into four stages: location survey, maintenance and multiplication of the pests B. longissima and T.brontispae parasite, parasite release and the evaluation of results. The results were; that there are three types of parasites, B.longissima coconut leaf pest in Ende (sub Ndona, Nangakeo and Ende) the eggs of the parasite Trichogrammatoideanana spp., the larvae and pupae of the parasite Tetrastichusbrontispae spp. and the 'Asecodeshispinarum Boucek'. T. Brontispae parasite being the most dominant parasite in each district with $10 \%$ level of parasitization of larvae and pupae of $60-90 \%$, biased sex male : female ratio. The pest capability of T.brontispae parasite in the laboratory was 6: 10 with a success rate of $90 \%$. The decline in the influence of parasite performance was unsincronized between phases from the phase of the insect host parasite in the field, the availability of insect host and time of release as well as climatic conditions not being conductive.
\end{abstract}

Keywords: B. longissima, T. brontispae, dominant parasitoids, parasitization ability 


\section{PENDAHULUAN}

Brontispa longissima Gestro (Coleoptera:Chrysomelidae) merupakan salah satu hama penting yang menyerang bangsa palm-palman di Asia Tenggara (Hosang, 2008), Dari 17 jenis palm termasuk didalamnya adalah kelapa, nipa, pinang dan beberapa tanaman hias menjadi inang dari $B$. longissima. Di beberapa provinsi di Indonesia hama tersebut telah menjadi hama utama pada kelapa. Dilaporkan penurunan hasil akibat serangan hama tersebut mencapai $30-40 \%$ dan 5\% dari tanaman yang terserang mengalami kematian (Nakamura, 2006). Penurunan hasil tersebut dianggap bernilai besar sebab penghasilan yang diperoleh dari kelapa tidak sebesar penghasilan dari komediti perkebunan yang lain dengan kata lain harga kelapa dipasaran masih relatif rendah.

Hama B. longissima dapat menyerang tanaman pada semua stadia umur, tetapi serangannya paling banyak ditemukan pada saat tanaman mulai berumur $4-5$ tahun khususnya di derah beriklim kering tingkat serangan hama tersebut lebih tinggi (Hosang 2008). Larva dan serangga dewasa $B$. longissimamenyerang jaringan daun muda (janur) kelapa, dengan gejala serangan daun berubah warna menjadi coklat sampai putih dan mengering. Gejala serangan ini mengakibatkan berkurangnya area fotosintesis yang tentunya secara tidak langsung dapat menurunkan produksi buah kelapa bahkan padaserangan berat akan mengakibatkan kematian pada tanaman. Upaya pengendalian telah dilakukan sejak hama tersebut ditemukan di Indonesia pada tahun 1919 - 1934 (Nakamura, 2006) namun hama tersebut tetap eksis. Dalam RENSTRA DISHUTBUN Kab. Ende untuk tahun 2006 - 2010 tertuang program peningkatan produktivitas tanaman perkebunan dengan salah satu upayanya adalah melakukan pengendalian OPT pada setiap jenis pertanaman. Dengan demikian upaya pengendalian OPT merupakan program pemerintah daerah yang menjadi prioritas pelaksanaannya dilakukan tiap tahun. Penyebaran hama B. longissima di Kabupaten Ende hampir merata di beberapa Kecamatan, dari data yang diperoleh memperlihatkan bahwa di Kecamatan Ende, Ende Timur, Ndona dan Ende Utara yang tersebar di 13 Desa dengan luas areal pertanaman $150 \mathrm{Ha}$ yang terdiri dari 15.000 pohon kelapa termasuk dalam kategori intensitas serangan berat (DISHUTBUN, 2008). Tindakan pengendalian yang telah diterapkan dibeberapa lokasi adalah dengan melakukan sanitasi, pemberian pestisida dengan cara absorbsi akar dan pelepasan musuh alami Tetratichus brontispae (DISHUTBUN, 2008). Pelepasan parasitoid T. brontispe terakhir dilakukan pada bulan Desember 2007 dan Januari 2008 sejumlah 5.220 ekor. Tingkat populasi B. longissima di lapang pada saat setelah dilakukan pelepasan musuh alami mengalami penurunan tetapi belum dapat mengendalikan populasi hama pada musim selanjutnya hal tersebut diperlihatkan dengan kemunculan $B$. longissima setiap tahun dengan intensitas serangan berat terutama pada bulan - bulan kering dan puncak penyerangannya terjadi pada bulan Januari - April.

Salah satu penyebabgagalnya tindakan pengendalian yang telah dilakukan adalah kurang baiknya system penangkalan disetiap pintu masuk daerah (karantina), sementara itu komoditas kelapa merupakan komoditas yang dibutuhkan oleh semua lapisan masyarakat dan kalangan industry sehingga peredaran dan perpindahan 
tempatnya sangat cepat. Kegagalan kedua adalah perilaku bercocok tanam petani yang menempatkan kelapa sebagai komoditas sampingan, sehingga teknik budidaya atau cara penanganan OPT tidak dilakukansecara intensif. Meskipun Dinas terkait telah mengupayakan tindakan pengendalian namunkegagalannya akan terjadi di tingkat petani. Ketiga penggunaan musuh alami di lapang memerlukan pendampingan dan pengawalan, karena petani tidak cukup cakap untuk melakukan hal tersebut.

Diperlukan suatu program PHT yang tepat dan menyeluruh agar masalah tersebut dapat terselesaikan. Program PHT tersebut mencakup studi bioekologi hama dan parasitoidnya dan teknik budidaya yang baik. Kegiatan studi bioekologi akan dipusatkan pada pemeliharaan parasitoid dominan dan perbanyakannya yang nantinya akan mengarah pada pelepasan untuk tindakan pengendalian.

Keberhasilan suatu tindakan pelepasan parasitoid yang telah dilakukan mempunyai indikator berupa kemapanan parasitoid tersebut secara mudah dan cepat. Hal tersebut berkenaan dengan teori "Three Generation Three Years" yang dikemukakan oleh Ev Chausen seorang ahli PHT dari California bahwa : a) parasitoid/predator yang efektif secara sempurna selalu mapan secara mudah dan cepat. b) parasitoid/predator yang gagal mapan secara mudah dan cepat merupakan indikator ketidak efektifan musuh alami tersebut. c) kolonisasi / pelepasan parasitoid atau predator eksotik dapat dihentikan selama tiga tahun apabila tidak ada bukti kemapanannya di lapang. Untuk itu kegiatan awal yang harus dilakukan adalah dengan mengetahui kolonisasi dan kemapanan parasitoid yang telah dilepaskan terdahulu untuk menemukan teknik pengendalian yang tepat. Disamping itu, perlu diketahui jenis jenis paraitoid yang ada di lapang dan bagaimana tingkat dominansinya serta kemampuan parasitisasinya dilapang. Sehingga kegiatan pemeliharaan dan perbanyakan akan dipusatkan pada parasitoid dominan dengan tingkat parasitisasi yang tinggi di lapang. Sampai saat ini jenis parasitoid yang telah dilepaskan dan diharapkan mampu mengendalikan populasi $B$. lingossima dilapang merupakan parasitoid yang berasal dari daerah lain, dan belum ada informasi yang lengkap mengenai jenis - jenis parasitoid yang ada di Kabupaten Ende dan tingkat parasitisasinya di lapang. Untuk itu penelitian ini dilakukan sebagai informasi berupa data yang akurat untuk menyusun program PHT yang akan diterapkan.

Hama B. longissima merupakan hama yang keberadaannya paling dominan dan selalu muncul setiap tahun. Teknik pengendalian yang telah diterapkan selama ini belum dapat mengendalikan populasi dan menurunkan tingkat serangan hama tersebut di lapang. Hal tersebut dikarenakan belum ditemukannya teknik pengendalian yang tepat dan tidak adanya informasi mengenai faktor - faktor penyebab terjadinya kegagalan usaha pengendalian yang telah dilakukan. Dengan mengetahui bioekologi hama dan musuh alaminya dan mengetahui faktor penyebab gagalnya teknik pengendalian terdahulu merupakan modal dasar dalam pengendalian hama $B$. longisimma selanjutnya yang akan dilakukan di lapang.

\section{BAHAN DAN METODE}

Penelitian ini dilaksanakan di kecamatan Nangakeo, Ndona dan Ende. 
Penelitian ini dilaksanakan selama 6 bulan dengan alokasi pengambilan sampel tiap kecamatan dilakukan sebanyak 4 kali. Penelitian dilakukan pada bulan Januari - Juni 2010.

Adapun yang menjadi parameter dalam pengamatan penelitian ini adalah :

1. Jenis parasitoid yang muncul (\%) Jenis parasitoid yang di dapat dari lapangan kemudian diidentifikasi dengan menggunakan kunci determinasi serangga serta mencocokkan dengan literatur yang ada, setiap jenis yang didapatkan pada setiap lokasi dikelompokkan berdasarkan jenisnya.

2. Dominansi parasitoid (\%)

Tingkat dominansi masing - masing jenis parasitoid yang muncul dihitung komposisinya dalam setiap lokasi pengambilan sampel untuk mengetahui tingkat dominansinya maka digunakan rumus :

$$
\begin{aligned}
& \mathrm{D}=\frac{\sum(\text { ni }(\text { ni-1 }))}{\mathrm{N}(\mathrm{N}-1)} \\
& \text { Dimana : } \\
& \mathrm{D}=\text { Dominansi } \\
& \mathrm{N}=\text { Jumlah total species } \\
& \mathrm{Ni}=\text { Jumlah suatu species }
\end{aligned}
$$

3. Tingkat parasitisasi parasitoid (\%) Tingkat parasitisasi atau kemampuan memarasit dari jenis parasitoid dominan akan dihitung berdasarkan rumus :

$$
\begin{aligned}
T P & =\frac{\sum \operatorname{Pr}}{\sum P} x 100 \% \ldots \ldots \ldots .(1) \\
T P & =\frac{\sum \operatorname{Pr}}{\sum P+\sum \operatorname{Pr}} x 100 \% \text {..(2) }
\end{aligned}
$$

Dimana :

$\mathrm{TP}=$ Tingkat Parasitisasi

$\mathrm{Pr}=$ Jumlah parasitoid yang muncul

$\mathrm{P}=$ Jumlah pupa yang muncul
Model pertama digunakan untuk parasitoid yang bersifat endoparasit. Model kedua digunakan untuk parasitoid yang ektoparasit.

4. Nisbah kelamin parasitoid (\%)

Nisbah kelamin pada umumnya nisbah kelamin yang normal adalah $1: 1$, namun demikian terdapat jenis serangga yang memiliki tipe reproduksi Thelytoki yaitu serangga yang menghasilkan individu individu betina pada setiap keturunannya.

$$
N B=\frac{P j}{\operatorname{Pr}} x 100 \%: N B=\frac{P j}{\operatorname{Pr}} x 100 \%
$$

Dimana :

NB : Nisbah Kelamin

$\mathrm{Pj}$ : Parasitoid Jantan

$\mathrm{Pb}$ : Parasitoid Betina

Pr : Parasitoid yang muncul

5. Keperidian parasitoid dominan $(\%)$ Keperidian merupakan indikator banyak atau tidaknya individu yang dapat dihasilkan, semakin tinggi tingkat keperidian maka semakin baik kinerja parasitoid tersebut. Keperidian diamati dengan cara menghitung jumlah keturunan pada setiap pupa terparasit.

6. Tingkat kolonisasi parasitoid yang telah dilepas (\%)

Tingkat kolonisasi parasitoid yang dianggap berhasil adalah kolonisasi yang dapat ditemukan setiap saat dipertanaman dengan jumlah yang cukup dan mapan pada ekosistemnya.

Bahan : alkohol 90\%, kapur anti semut, daun terserang yang masih terdapat telur, larva maupun pupa $B$. lingossima.

Alat : cool box, hand score, botol koleksi, toples penetasan, kuas, label, mikroskop, tabung reaksi, kain kasa, 
lem kastol, karet, tabung banbu, cutter, guntung, alat tulis.

Pelaksanaan penelitian meliputi hal - hal berikut :

\section{Survey}

Survey lokasi dilakukan untuk menetapkan lokasi pengambilan sampel pada tiap Kecamatan yang telah ditentukan sebagai area penelitian. Selain untuk mengetahui tingkat serangan B. longisimma dan keberadaan parasitoidnya di lapang dengan mengambil beberapa bagian tanaman terserang yang masih mengandung telur, larva, pupa maupun imago dan diidentifikasi di laboratorium, juga dilakukan pengoleksian parasitoid dominan sebagai indikator kolonisasi dan kemapanan parasitoid tersebut dilapang.

\section{Pembuatan dan percobaan instrumen penelitian}

Percobaan instrumen penelitian dilakukan untuk mengetahui ketepatan daya guna dari instrumen tersebut. Dalam hal ini yang perlu dicoba adalah pembuatan dan percobaan toples penetasan bagi $B$. longisimma dan parasitoidnya, teknik pengambilan sampel dilapangan, teknik pemeliharaan dan perbanyakan dan teknik identifikasi di laboratorium

\section{Perbanyakan parasitoid dominan}

Imago $B$. longissima diperoleh dari lapangan. Sekitar 20 ekor imago dimasukkan ke dalam tabung reaksi yang telah berisi daun muda kelapa (janur) segar, sebagai bahan pembiakan. Setelah 24 jam janur (tanaman inang) yang telah diteluri dipindahkan ke dalam tabung lain dan diganti dengan pakan baru. Kegiatan tersebut dilakukan berulang - ulang sampai persediaan serangga inang dan instar inang terpenuhi. Pemeliharan janur yang telah diteluri dilakukan sampai telur menetas dan berkembang menjadi larva instar-3 (jika janur layu, maka telur B. longissima dipindahkan ke wadah yang telah dikondisikan sesuai bagi perkembangan telur $B$. longissima dengan menggunakan kuas), pakan terus diganti selama fase larva hingga larva telah siap menjadi pupa, pupa yang siap menetas dipindahkan ke dalam wadah plastik penetasan yang berdiameter $20 \mathrm{~cm}$ dan tinggi $30 \mathrm{~cm}$. Imago yang muncul kemudian digunakan untuk pembiakan selanjutnya.

Imago parasitoid yang telah diidentifikasi dimasukkan ke dalam kurungan pemeliharaan yang berisi janur yang telah terinfestasi larva $B$. longissima instar-2. Sebagai pakan tambahan untuk menjaga kebugaran parasitoid diberikan larutan madu $10 \%$ yang dicelupkan kertas kalender, kemudian kertas dimasukkan ke dalam kurungan . Infestasi dilakukan selama 24 jam. Tanaman inang yang telah terinfestasi oleh parasitoid dipindahkan ke dalam tabung lain. Tanaman inang tersebut diganti dengan tanaman inang baru yang telah terinfestasi larva $B$. longissima instar-2, kegiatan ini diulang hingga persediaan parasitoid terpenuhi. Setelah tiga hari infestasi (hsi) janur yang telah berisi pupa inang terparasit dipindahkan kedalam stoples penetasan. Pengambilan imago parasitoid dilakukan pada hari ke-7 sampai hari ke-14 hsi. Imago yang muncul digunakan sebagai bahan penelitian selanjutnya. Prosedur kerja dapat dilihat pada Gambar 4.1 berikut :

\section{Pelepasan}

Brontispa longisima merupakan serangga nucturnal yaitu serangga yang melakukan aktivitasnya pada malam hari. Oleh sebab itu pemilihan waktu yang tepat untuk melakukan pelepasan adalah hal mendasar yang perlu 
diketahui. Waktu pelepasan parasitoid yang dianggap efektif adalah pada senja hari. Pelepasan parasitoid akan dilakukan secara serempak ditiap kecamatan dengan mencoba melakukan teknik pelepasan secara augmentasi. Pelepasan dilakukan dengan dua cara yaitu melepas pupa $b$. longissima yang telah terparasit $T$. brontispae dan melepas imago $T$. brontispae yang telah menetas kurang lebih satu jam. Proses pelepasan dapat dilihat pada gambar 4.2 berikut :

\section{Pengamatan}

Pengamatan yang dilakukan di laboratorium diawali dari proses identifikasi parasitoid dan pada saat perbanyakan (jumlah parasitoid yang muncul, keperidian, nisbah kelamin dan tingkat parasitisasinya). Pengamatan dilapangan dilakukan pada saat setelah melakukan pelepasan parasitoid (kolonisasi dan kemapanan).

\section{Analisis Data}

Data - data kuantitatif dianalisis secara statistik dengan analisis varian Tabel 1. Dominansi jenis parasitoid pada tiga lokasi pengamatan.

\begin{tabular}{llc}
\hline \multicolumn{1}{c}{ Jenis Parasitoid } & Lokasi & Dominansi (\%) \\
\hline Trichogrammatoideanana Zehnter & Nangakeo & 15 \\
Tetrastichusbrontispae Ferriere & & 26 \\
Asecodeshispinarum Boucek & & 18 \\
\hline Trichogrammatoideanana Zehnter & Ndona & 3 \\
Tetrastichusbrontispae Ferriere & & 15 \\
Asecodeshispinarum Boucek & & 13 \\
Trichogrammatoideanana Zehnter & Ende & 11 \\
Tetrastichusbrontispae Ferriere & & 39 \\
Asecodeshispinarum Boucek & & 18 \\
\hline
\end{tabular}

Keterangan : data telah di analisis menggunakan indeks dominansi simpson's

Tetrastichus brontispae Ferriere merupakan jenis musuh alami dengan tingkat dominansi paling tinggi di tiga kecamatan secara berturut - turut kecamatan Nangakeo (26\%), Ndona (15\%) dan Ende (39\%) hal tersebut (tingkat parasitisasi, keperidian, nisbah kelamin dan dominansi masing masing parasitoid). Sementara untuk data - data diskriptif dianalisis secara kualitatif (Gasperz, 1991).

\section{HASIL DAN PEMBAHASAN}

\section{Jenis dan Dominansi Parasitoid}

Jenis musuh alami (parasitoid) pengendali $B$. longissima yang ditemukan di lapangan sebanyak tiga jenis yaitu parasit telur Trichogramma toideanana Zehnter (Hymenoptera : Trichogrammatoidae), parasit larva dan pupa adalah Tetrastichus brontispae Ferriere (Hymenoptera : Eulophydae) dan Asecodes hispinarum Boucek. Namun demikian dari ketiga jenis tersebut T.brontispae Ferriere (Hymenoptera : Eulophydae) merupakan jenis parasitoid yang paling dominan pada setiap lokasi (Nangakeo 26\%, Ndona 15\% dan Ende 39\%). Data persentase dominansi disajikan dalam tabel berikut : 
Zhou (2006) yang menyatakan bahwa T.brontispae merupakan parasitoid monofag yang secara umum terbatas pada satu species inang dan parasitoid tersebut juga merupakan endoparasit yang meletakkan telur di dalam tubuh inang. Parasitoid yang bersifat monofag memiliki kemampuan yang lebih baik dalam mengendalikan populasi hama di lapang dibandingkan dengan jenis parasitoid yang bersifat polyfag.

Berdasarkan sifat dan kemampuan yang dimiliki oleh T. Brontisphae maka jenis parasitoid ini dapat dijadikan sebagai agen pengendali hayati untuk menekan populasi hama $B$. longissima di lapang.

\section{Tingkat Parasitisasi Parasitoid Tetrastichus brontispae}

Tingkat parasititasis adalah kemampuan parasitoid untuk memarasit atau mematikan serangga inang yang ditandai dengan banyakanya mortalitas serangga inang dan tingginya tingkat keperidian serta nisbah kelamin yang ideal. Parameter tersebut merupakan kriteria musuh alami yang efektif untuk mengendalikan populasi serangga inang di lapang. Tetrastichus brontispae yang dikembangkan di laboratorium dengan suhu rata - rata $32^{\circ} \mathrm{C}$ dan kelembaban rata - rata $79 \%$ memiliki tingkat parasitisasi yang baik yaitu berkisar 40 $80 \%$. Data tingkat parasitisasi $T$. brontispae yang diuji dalam laboratorium pada 10 ekor $B$. longissima dengan 10 kali pengulangan diperlihatkan pada tabel berikut :

Tabel 2 Tingkat Parasitisasi T. brontispae pada berbagai komposisi

\begin{tabular}{ccc}
\hline Imago T. Brontispae & Pupa B. longissima & Tingkat Parasitisasi (\%) \\
\hline 1 & 10 & $0 \mathrm{~d}$ \\
2 & 10 & $0 \mathrm{~cd}$ \\
3 & 10 & $40 \mathrm{bc}$ \\
4 & 10 & $46 \mathrm{~b}$ \\
5 & 10 & $62 \mathrm{~b}$ \\
6 & 10 & $80 \mathrm{a}$ \\
7 & 10 & $31 \mathrm{bc}$ \\
8 & 10 & $0,67 \mathrm{c}$ \\
9 & 10 & $0,43 \mathrm{c}$ \\
10 & 10 & $0,16 \mathrm{~cd}$ \\
\hline
\end{tabular}

$\overline{\text { Keterangan : huruf yang sama pada kolom yang sama menandakan pengaruh yang tidak }}$ berbeda nyata pada uji duncan's taraf 5\%

Persentase mortalitas pupa $T$. brontispae terendah diperlihatkan pada perlakuan $1: 10$ dan $2: 10$. Hal tersebut memperlihatkan bahwa satu dan dua ekor larva belum mampu memarasit pupa B. longissima di dalam tabung, dengan kata lain semakin tinggi populasi parasitoid maka semakin tinggi tingkat parasitisasi (Okmar dan Bind, 2004). Pola interaksi parasitoid dan populasi hama di alam adalah mengikuti pola perkembangan inangnya sehingga apabila hama di lapang meningkat maka populasi parasitoid juga semakin meningkat dan sebaliknya (Wahyuni, 2006).

Penurunan tingkat parasitisasi $T$. Brontispae diperlihatkan pada perlakuan $8: 10(0,67 \%) ; 9: 10$ $(0,43 \%)$ dan $10: 10(0,16 \%)$. Keadaan yang demikian diperkirakan karena terjadi kompetisi antara parasitoid untuk memperebutkan serangga inang. Wahyuni (2006) menjelaskan bahwa 
proses parasitisasi juga dapat dipengaruhi karena adanya faktor kompetisi secara intraspesifik maupun interspesifik. Persaingan intraspesifik yaitu persaingan yang terjadi antara individu - individu sejenis sedangkan persaingan interspesifik yaitu persaingan yang terjadi antara dua jenis yang berbeda. Persaingan terjadi akibat adanya perebutan makanan, ruang tempat tinggal, cahaya dan sebagainya (Nicholson, 1954 dalam Price, 1984). Keadaan yang demikian menandakan bahwa dalam proses bereproduksi, umumnya suatu jenis parasitoid akan melewati tahapan - tahapan parasitisasi agar parasitoid berhasil memarasit inangnya.

Sebelum proses peneluran berlangsung imago $T$. brontispae terlebih dahulu melakukan pendekatan terhadap inang. Pertanda yang digunakan untuk mendeteksi keberadaan inang meliputi senyawa kimia yang dihasilkan oleh inang berupa cairan ataupun kotoran dan pertanda fisik seperti ukuran, bentuk ataupun tekstur inang (Sofia, 2008).

Tetratichus brontispae merupakan jenis parasitoid endoparasit yaitu parasitoid yang memarasit dari dalam tubuh serangga inang. Ciri khas dari tipe parasitoid ini adalah memiliki kemampuan melakukan host feeding yaitu perilaku parasitoid sebagai usaha untuk memperoleh makanan dengan cara mengambil atau menghisap tubuh inangnya. Host feeding memiliki perangan yang sangat penting bagi serangga betina untuk memenuhi kebutuhan protein dalam tubuhnya untuk memproduksi telur (Ueno, 1998). Peristiwa host feeding diperlihatkan pada perlakuan pada perlakuan $8: 10,9$ : 10 dan $10: 10$, dimana pada ketiga perlakuan tersebut meunjukkan kegagalan T.brontispae untuk menjadi imago karena adanya peristiwa kompetisi antara imago - imago T.brontispae. Telur T.brontispae yang telah di letakkan pada inang akan mengalami kegagalan menetas karena inang yang sama telah di host feeding oleh imago T.brontispae lain yang mengakibatkan larva T.brontispae yang ada di dalam tubuh serangga inang mengalami kekurangan cairan dan akhirnya gagal menetas.

\section{Nisbah Kelamin dan Keperidian Tetratichus brontispae}

Nisbah kelamin dan keperidian $T$. Brontispae yang diberi perlakuan kombinasi perbandingan pupa B.longissima disajikan dalam tabel 3 berikut :

Tabel 3. Nisbah kelamin dan keperidian T.brontispae pada setiap perlakuan

\begin{tabular}{cccc}
\hline Imago T. brontispae & Pupa B. longissima & Nisbah kelamin & Keperidian (\%) \\
\hline 1 & 10 & $0: 0$ & $0 \mathrm{e}$ \\
2 & 10 & $0: 0,8$ & $0,2 \mathrm{e}$ \\
3 & 10 & $1: 1,27$ & $49 \mathrm{bc}$ \\
4 & 10 & $1: 1,48$ & $58 \mathrm{~b}$ \\
5 & 10 & $1: 1,53$ & $97 \mathrm{a}$ \\
6 & 10 & $1: 1,58$ & $100 \mathrm{a}$ \\
7 & 10 & $1: 1,46$ & $46 \mathrm{bc}$ \\
8 & 10 & $1: 1,05$ & $7 \mathrm{~d}$ \\
9 & 10 & $0: 1$ & $6 \mathrm{~d}$ \\
10 & 10 & $0: 1$ & $6 \mathrm{~d}$ \\
\hline
\end{tabular}

Keterangan : huruf yang sama pada kolom yang sama menyatakan pengaruh yang tidak berbeda nyata pada uji duncan's taraf 5\% 
Tabel 3 di atas memperlihatkan hasil terendah pada nisbah kelamin secara adalah perlakuan $1: 10(0: 0)$ dan 2 : $10(0: 0,8)$ dan diikuti dengan tingkat keperidian terendah. Hal tersebut terjadi diperkirakan karena satu dan dua individu T.brontispae belum mampu mengendalikan 10 ekor pupa B.longissima di dalam tabung. Kegagalan T.brontispae menetas pada perlakuan $1: 10$ dan $2: 10$ disebabkan masih banyaknya kandungan lemak pada pupa yang menghambat proses keluarnya T.brontispae dari pupa B.longissima yang ditandai dengan gagalnya pupa B.longissima menjadi imago. Kemungkinan lain karena terjadinya hamabtan pada proses pengenalan inang yang dilakukan oleh T.brontispae.

Tingkat keperidian tertinggi diperlihatkan pada perlakuan $6: 10$ (100\%) dan $7: 10$ (97\%). Keadaan yang demikian menandakan bahwa 6 ekor T.brontispae memiliki kemampuan terbaik untuk memarasit 10 ekor B.brontispae, hal tersebut diperkuat dengan tingkat nisbah kelamin yang bias betina. Individu - individu betina merupakan parasitoid yang dapat bekerja efektif untuk menurunkan tingkat populasi hama di lapang sebab individu - individu betina yang mampu menghasilkan dan meletakkan telur atau memarasit inangnya, keadaan yang demikian tidak terjadi pada individu individu jantan.

\section{Tingkat Kolonisasi Parasitoid Tetratichus brontispae}

Daya parasitisisasi T. Brontispae berbeda di laboratorium dan lapangan. Perbedaan tersebut disebabkan oleh beberapa faktor diantaranya faktor makanan dan lingkungan. Daya parasitisasi yang baik ditandai dengan tingkat keperidian yang tinggi dan kemampanan parasitoid membentuk koloni. Tingkat kolonisasi di simbolkan dengan skor dimana satu ekor $B$. Longissima dapat diparasit oleh 3 ekor T.brontispae. Tabel 4 berikut menampilkan data kolonisasi yang terbentuk setelah dilakukan pelepasan pada waktu pelepasan yang berbeda kecamatan Nangakeo, Ndona dan Ende.

Tabel 4. Tingkat kolonisasi T.brontispae yang telah dilepaskan di lapangan pada setiap kecamatan

\begin{tabular}{|c|c|c|c|c|c|}
\hline \multirow{2}{*}{ Lokasi } & \multicolumn{4}{|c|}{ Interval Pengamatan dan Tingkat Kolonisasi } & \multirow{2}{*}{ Waktu aplikasi } \\
\hline & $2 \mathrm{msi}$ & $4 \mathrm{msi}$ & $6 \mathrm{msi}$ & $8 \mathrm{msi}$ & \\
\hline Nangakeo & 1 & 1 & 2 & 2 & 17.00 \\
\hline Ndona & 1 & 0 & 1 & 1 & 15.00 \\
\hline Ende & 0 & 0 & 0 & 1 & 08.00 \\
\hline
\end{tabular}

Keterangan :

msi : minggu setelah investasi

skor $0 \quad:<3$ ekor $T$. brontispae : 1 ekor B. longissima

skor 1 : 3-6 ekor T.brontispae : 1 ekor B.longissima

skor 2 : > 6 ekor T.brontispae : 1 ekor B.longissima

Tabel 4 memperlihatkan adanya perbedaan tingkat dominansi berdasarkan waktu aplikasi disetiap kecamatan. Pada kecamatan Nangakeo, pelepasan parasitoid dilakukan pada jam 17.00 memiliki tingkat kemampanan parasitoid yang lebih baik jika dibandingkan dengan kecamatan Ndona 
(pukul 15.00) dan Ende (pukul 08.00). Keadaan yang demikian telah diperlihatkan pada pengamatan $2-8$ msi.

Brontispa longissima merupakan serangga nocturnal yaitu jenis serangga yang aktif pada malam hari. Sementara itu parasitoid T.brontispae merupakan parasitoid yang tidak memiliki masa praoviposisi yaitu dapat menghasilkan tulur sesaat setelah menetas. Keadaan yang demikian menyebabkan T.brontispae yang diinvestasikan di lapang harus segera dapat menemukan makanannya. Oleh sebab itu tingkat keberhasilan pelepasan T.brontispae di alam paling baik dilakukan pada saat pada saat T.brontisphae dalam fase pupa instar akhir dengan waktu pelepasan sore hari.

Selain faktor waktu pelepasan, faktor lain yang perlu diperhatikan adalah sinkron tidaknya fase aktif T.brontispae dengan fase inang yang tersedia di lapang. Hal tersebut disebabkan karena $T$. brontispae memiliki daya predasi yang berbeda terhadap fase larva dan pupa B.longissima. Tingkat parasitisasi T.brontispae sebesar $10 \%$ pada larva dan $80 \%$ pada pupa B.longissima. Keadaan tersebut diperkuat oleh penelitian Sihombing (2009) yang menyatakan bahwa $B$. longissima pada fase larva lebih aktif sehingga tingkat parasitisasi T.brontispae hanya mencapai $10 \%$ sedangkan tingkat parasitisasi T.brontispae pada fase pupa mencapai 60-90\%, (Rethinan dkk 2007). Fenomena tersebut menandakan bahwa sinkronisasi antara parasitoid dengan fase ketersediaan inang sangat mempengaruhi tingkat keberhasilan kinerja parasitoid di lapang.

Kondisi iklim juga sangat berpengaruh terhadap kemapanan parasitoid di alam. Pada pengamatan 4 msi di kecamatan Ndona dan Ende terjadi hujan deras, kondisi tersebut menyebabkan terjadinya penurunan populasi T.brontispae yang ditemukan di alam sementara populasi B.longissima masih banyak di pertanaman. Hal tersebut disebabkan karena B.longissima pada fase telur hingga imago berada di dalam janur yang mengakibatkan B.longissima dapat terlindungi dari air hujan. Sementara imago T.bronthispae hidup bebas.

\section{KESIMPULAN}

\section{Kesimpulan}

Kesimpulan yang dapat disusun dari hasil penelitian ini adalah sebagai berikut :

1. Terdapat tiga jenis parasitoid hama janur kelapa B.longissima yang ada di Kabupaten Ende (kecamatan Ndona, Nangakeo dan Ende) yaitu parasit telur Trichogrammatoideanana Zehnter (Hymenoptera

Trichogrammatoidae), parasit larva dan pupa Tetrastichusbrontispae Ferriere (Hymenoptera : Eulophydae) dan Asecodeshispinarum Boucek.

2. Parasit T. brontispae merupakan parasitoid dominan pada setiap kecamatan dengan tingkat parasitisasi larva $10 \%$ dan pupa $60-$ $90 \%$, Nisbah kelamin yang bias betina.

3. Kemampuan Parasitisisasi T.brontispae terbaik di laboratorium adalah $6: 10$ dengan tingkat keberhasilan sebesar $90 \%$.

4. Penurunan kinerja parasitoid di pengaruhi oleh ketidaksinkronan antara fase parasitoid dengan fase serangga inang di lapang, ketersediaan serangga inang dan waktu pelepasan serta kondisi iklim yang tidak kondusif. 


\section{UCAPAN TERIMAKASIH}

Pada kesempatan yang baik ini penulis ingin mengucapakan terimakasih yang sebesar - besarnya kepada DIKTI Cq. DP2M atas dana yang diberikan demi terlaksananya penelitian ini, kepada Yapertif, Universitas Flores Cq. Lembaga Penelitian Universitas Flores dan Fakultas Pertanian atas dukungan dan perijinannya, Dinas Perkebunan dan Kehutanan Kabupaten Ende Cq. UB. Laboratorium Agen Hayati Ndona atas fasilitas yang diberikan, Bapak Camat Nangapenda dan Ende Selatan atas kerjasamanya, Sdri. Maria Goreti Nere yang telah membantu dalam proses penelitan serta semua pihak yang telah membantu terlaksananya penelitian ini.

\section{DAFTAR PUSTAKA}

Berryman A.A. 1981. Population System. New York : A General Press.

Clark, L.R., Geler P.W., Hughes R.D., Norris R.F. 1976. The Ecology of Insects Population in Theory and Practice. London : Chapman and Hall.

Dishutbun. 2008. Rencana Stratejik Dishutbun Tahun 2006 S/d 2008.

FAO. 2004. Report of the Expert Consultations on Coconut Beetle Outbreak in APPPC Member Countries.

Hosang,M.L.A., Jelfina C.A., Novarianto, H. 1996. Biological control of Brontispa longissima (Gestro) in Indonesia. Malayan Agricultural Journal, Vol. 124:37-52
Lever, R. A. W. 1951. Malayan Agricultural Journal, Vol. 34:7982

Nakamura,S., Konishi,K.,Takatsu, K. 2006. Invasion of Coconut Hispine Beetle, Brontispa longissima :Current Situation and Control Measures in Southeast Asaia. Malayan Agricultural Journal, Vol. 234:69-73

O'Connor, B.A. 1940. Notes of the Coconut Leaf Hispid, Brontispa froggatti Sharp and its Parasites. The New Guinea Agryculture Gazette. 6:36-40

Okmar and Bind, 2004. Prey Quality Dependent Growth, Develpment and Reproduction of a Biocontrol Agent, Cheilomenes sexmaculata (Fabricus) (Coleoptera : Coccinellidae). iBiocont. Sci. Tech.

Sihombing, M.B. 2009. Uji Parasitisasi Tetrastichus brontispae (Hymenoptera : Eulophidae) Terhadap Kumbang Janur Kelapa Brontispa longissima (Coleoptera : Chrysomilidae). Skripsi. Universitas Sumatera Utara. Medan.

Ueno,T. 1998. Selective Host-feeding on Parasitized Host by the Parasitoid Itoplectis narayae (Hymenoptera : Ichneumonidae) and its Implications for Biological Control. Bull. Entomol. Res. CAB International.

Trimurti, H dan Yeherwandi. 2006. Pengendalian Hayati Hama dan 
Penyakit Tumbuhan. Andalas University Press. Padang

Vinson, S.B., Iwantsch, G.F. 1980. Host Suitability for Insect Parasitoid. Annu. Rev. Entomol 25 : 397 419.

Water House, D.F., Norris,K.R.1987. Biological Control : Pacific
Prospects. ACIAR Inkata Press Melbourne. 134-141

Wahyuni, S. 2006. Studi Kompetisi Beberapa Jenis Parasitoid Terhadap Lalat Pengorok Daun Liriomyza huidobrensis Blanchard (Diptera Agromyzidae). Tesis. Universitas Udayana. Denpasar 